\title{
AN EMPIRICAL STUDY ON AVAILABILITY OF RURAL HEALTH CARE SERVICES IN ZAROL VILLAGE AS PER THE INDIAN PUBLIC HEALTH STANDARDS
}

\author{
Anupam Mitra \\ TeamLease Skills University India \\ E-mail: anupam.mitra@teamleaseuniversity.ac.in
}

Shivangi Shukla

TeamLease Skills University India

E-mail: shivangi.s@teamleaseuniversity.ac.in

Submission: $25 / 04 / 2018$

Revision: 10/05/2018

Accept: 15/06/2018

\section{ABSTRACT}

A study on availability of Health care services in Zarol village as per the Indian Public Health Standards has been undertaken with the main objective to find out the prevailing gap between expected health standards and actual Indian Public health standards. A sample of 80 respondents was undertaken for the survey. Data were collected through structured closed ended questionnaire using Non-probability convenience sampling method through personally interviewing the respondents. The Service Quality Dimensions were used to measure the Service Quality Assurance of Public Health care services. Research result reveals that means score of major service quality dimensions is relatively high indicating higher level of patient's satisfaction from PHC of Zarol. Whereas the mean score of only personnel quality and safety measures having relatively low score indicating lower level of patient's satisfaction.

Keywords: Quality Assurance, Service Quality Dimensions, Indian Public Health Standards, Public Health Care Services 


\section{INTRODUCTION}

"Services are economic activities offered by one party to another. Often timebased, performances bring about desired results to recipients, objects or other assets for which purchasers have responsibility. In exchange for money, time and effort, service customers expect value from access to goods, labor, professional skills, facilities, networks and systems, but they do not take ownership of any of the physical elements involved" 1

As per the Planning Commission, a town with a most extreme populace of 15,000 is viewed as provincial in nature.

The National Sample Survey Organization (NSSO) characterizes 'rural' as the area with a populace density of up to 400 for every square kilometer. Villages with clear reviewed limits yet no city board and at least $75 \%$ of male working populace engaged in agribusiness and associated exercises.

Health care sector is playing a dynamic role for the overall health of our country. Despite the fact that there are such a large number of changes in the setting of Indian Rural Health Care Services yet with regards to country's overall health care scenario.

Guidelines are a methods for depicting a level of value that the health care centers are relied upon to meet. A Primary Health Center fills in as the first port of call to a qualified specialist in the public health care division in provincial zones giving a scope of Curative, Promotive and preventive health care services. A PHC furnishing 24 hours services and with proper linkages, assumes a critical part of expanding institutional conveyances accordingly diminishing maternal mortality and infant mortality.

${ }^{1}$ Adapted from a definition by Christopher Lovelock (identified anonymously as Expert 6, Table II, p.112) in Bo Edvardsson, Anders Gustafsson, Inger Roos, "Service Portraits in Service Research: A Critical Review", International Journal of Service Industry Management, 16, No.1,2005, 107-121. 
DOI: 10.14807/ijmp.v10i1.817

\section{RURAL HEALTHCARE SYSTEM IN INDIA}

The rural healthcare services framework in India has been created as a three level framework containing the following:

a) The Community Health Center ( $\mathrm{CHC}$ ) - A 30 bed clinic/referral unit for 4 PHCs with authority administrations. (Rustic Health Statistics in India 2012)

b) The Primary Heath care center (PHC) - A referral unit for 6 (4-6 bed) sub focuses staffed by a medical officer in charge and 14 paramedics. (RUSTIC HEALTH STATISTICS IN INDIA, 2012)

c) 3.The Sub Center-The most fringe purpose of contact between the Primary Healthcare system and the community, staffed by 1 Health Worker-Female (HM-F)/Auxiliary Nurse Midwife (ANM) and 1 Health Worker-Male (HW-M) (RURAL HEALTH STATISTICS IN INDIA, 2012)

\subsection{Primary Health Centers (PHCs)}

$\mathrm{PHC}$ is the main contact point between village community and the Medical Officer. The PHCs were imagined to give an incorporated curative and preventive health care to the country populace with emphasis on preventive and primitive parts of medicinal services. The PHCs are set up and kept up by the State Governments under the Minimum Needs Program. PHC acts as a referral unit for 6 Sub Centers and has 4-6 beds for patients. The activities of PHC involve curative, Preventive, Promotive and family welfare services.

\section{LITERATURE REVIEW:}

\subsection{Mosad Zineldin, (2006)}

Service quality is a multidimensional concept and in order to operationalize it many variables have to be considered. SERVQUAL is a widely used scale to measure different quality dimensions. Originally, as developed by Parasuraman, Zeithaml e Berry (1985), scale consisted ten dimensions used by the customer to Judge Company's service, which were reduced into five major dimensions (CRONIN; TAYLOR, 1992): tangibles, reliability, responsiveness: assurance and empathy.

The SERVQUAL constructs impact is used to measure service quality and to identify service quality gaps but not their root causes for which other approaches are needed (WISNIEWSKI; WISNIEWSKI, 2005). 
Some efforts have been invested to improve the methods. In this research we describe a study involving a new instrument and a new method that assures a reasonable level of relevance, validity and reliability, while being explicitly change oriented.

\subsection{Leo van der Reis Qian Xiao Grant Savage, (2007)}

To achieve the goal of a truly caring commonwealth, we must improve quality and safety in health care, increase access and utilization of technology, promote greater consumer involvement at all stages, restructure the medical malpractice system to reach all who may be injured by systemic errors, and develop sustainable financing less subject to the vagaries of state revenues.

However, the access issue still remains a basic and important problem we have to confront. The rapidly evolving nature of the health care system presents both enhanced opportunities to address the access problem and new threats to the fragile health care system. However, with the efforts and resources of communities, providers, government, and others to create viable long-term solutions, a good tendency can be expected.

For example, Senate Bill No. 738 - the Health Access and Affordability Act, a petition from the Committee on Health Care Financing - appears strongest in its objectives to offer full health care coverage that is universal and continuous, and is affordable to individuals and families (MOORE, 2005).

\subsection{Gyan Prakash, (2015)}

There are few relevant healthcare regulations and their enforcement is weak. Social regulation is at best weak and economic regulation is non-existent. Patients have poor role-awareness, do not appreciate their responsibilities and their rights are limited.

Partnership and coordination among various health institutions are weak and managers in each institution are more concerned about their functions. Selfregulation among healthcare professionals is fragile and services are inefficient. The author contributes to the healthcare literature, first, by synthesizing the literature and identifying healthcare issues and challenges, and emphasizes regulation in molding healthcare service delivery. 
Broader experiences in the literature suggest that governments in emerging economies are yet to synergize technical and functional quality for an allencompassing service delivery. These issues seem to be well resolved in developed economies; however, healthcare shattering, long waiting times and underlying payment mechanisms need attention.

\subsection{Hardeep Chahal Shivani Mehta, (2013)}

Theoretically, the study confirmed that all patient satisfaction dimensions are significant in assessing patient satisfaction which validate the existing findings of various researchers such as Raftopoulous (2005), Kang and James (2004), Chahal and Sharma (2004); Sardana (2003); Brady and Cronin (2001); Corbin et al. (2001); Newman et al. (1998); Gilson et al. (1994).

Besides, model testing conducted also provides new insight to understand the relationship between patient satisfaction dimensions and loyalty. The study also contributes in the understanding of patient behavior and their medical needs in general, which can be used for increasing patient satisfaction in particular.

It is also found that to retain patients and to improve relations with the patients; the medical staff must show concern and sympathy for the patients, which results in easy recovery, improved services, and above all, improved patient satisfaction and loyalty. The findings suggest that training programs on patient relationship management at least once a year, along with spiritual discourses should be considered and organized to inculcate the changes in the attitude and behavior of staff towards patients.

The patient-staff interactions (physicians, nurses and supportive staff) and their impact on satisfaction and loyalty are significant to understand patients' behavior and to improve the image of the hospital over competitors. Further, the patient-oriented approach will help the Indian health service provides in linking their technological and non-technological factors to the unserved needs of the patients which, in turn, will help in enhancing the degree of patient satisfaction.

Strategies such as responding to patients' enquiry promptly, bridging the communication gap between patients and medical personnel, becoming more friendly and understanding to the problems of patients, maintaining cleanliness in the units, both internally and externally, providing regular report regarding the patients' 
progress without waiting for them to demand, providing a grievances system in the unit, conducting surveys to know about the attitude of the patients with regard to the employees, adopting patient-oriented policies and procedures, solving patientrelated problems immediately and providing every type of essential facility should be implemented by the hospitals in India for improving and maintaining high patient satisfaction.

\section{RELEVANCE OF THE STUDY}

The fundamental issue hidden for rural health care is because of health issues or poor health services, the work efficiency of provincial people is at great hazard. It has been seen in a few villages that, the accessibility and nature of health care services are in the extremely poor state regardless of immense consumption and endeavors from the government.

Along these lines, there are such a significant number of issues have turned out; this research will unquestionably yield the constructive results on the said issues to Government and to the village individuals

Due to non-accessibility to Public Health care and low quality of medicinal services benefits, a major share of individuals in India swing to the nearby local private health center as their first decision of care. In any case, private medicinal services are costly, regularly unregulated and variable in quality.

Other than being temperamental for the unskilled, it is additionally not affordable by lower income groups. The key difficulties in the public health care services are low nature of care, poor responsibility, lack of awareness, and restricted access to facilities.

Individuals in rural zones confront some unique medical problems than individuals who live in towns and urban areas. Getting health care services can be an issue when individuals live in a remote zone. They won't not have the capacity to get to a healing center rapidly in a crisis. They additionally might not have any desire to venture out long separations to get normal registration and screenings. Rural areas mostly have fewer specialists and dental practitioners, and certain experts won't be available at all

In rural areas health care services are mainly provided by: 
a) Government / government sponsored health centers or hospitals.

b) A charitable trust run health centers or hospitals.

c) Private practitioners.

\subsection{Objectives:}

To analyze the actual scenario of Rural Health Care Services in Zarol village and to measure the satisfaction level of patients

\subsection{Research methodology}

Research Design is a framework or blue print for conducting the marketing research project. It specifies the details of the procedures necessary for obtaining the information needed to structure and solve marketing research problems. For this study, we used survey method by personally interviewing respondents through closed ended questionnaire

\subsubsection{Scope of the Study}

The scope of study is Zarol village in the state of Gujarat.

\subsubsection{About Zarol:}

Zarol is a village situated in Nadiad Taluka of Kheda district, Gujarat with total 293 families residing. The Zarol village has a population of 1379 of which 707 are males while 672 are females as per Population Census 2011. 2

\subsubsection{The sample}

The actual user of specific service will constitute the sample of the study. Sample of 80 respondents has taken for the survey.

\subsubsection{Statistical Analysis}

For Data analysis, various statistical tests were used such as, Frequency distribution, Cronbach's alpha for checking reliability, Mean, Standard Deviation as Descriptive Statistics, and Independent Sample T-test for equality of means and Analysis of Variance (ANOVA).

Quantitative research methods were used to measure availability of health care services by applying above mentioned statistical tests.

\footnotetext{
2 http://www.census2011.co.in/data/village/517602-zarol-gujarat.html
} 
INDEPENDENT JOURNAL OF MANAGEMENT \& PRODUCTION (IJM\&P)

http://www.ijmp.jor.br

v. 10, n. 1, January - February 2019

ISSN: 2236-269X

DOI: 10.14807/ijmp.v10i1.817

\subsubsection{Interview Script}

Name

Gender

Age group

Qualification

Marital status

$\begin{array}{cc}\text { Male } & \text { Female } \\ \text { Below 25 } & 25 \text { to } 35 \\ \text { Illiterate } & \text { SSC } \\ \text { Single } & \begin{array}{l}\text { Married(Not } \\ \text { having kids) }\end{array}\end{array}$

Female
25 to 35
SSC
Married(Not
having kids)
36 to 45
HSC
Married
46 or above
Bachelors
Divorced

(Having kids)

Masters

Village

Table 1: Factors and Satisfaction

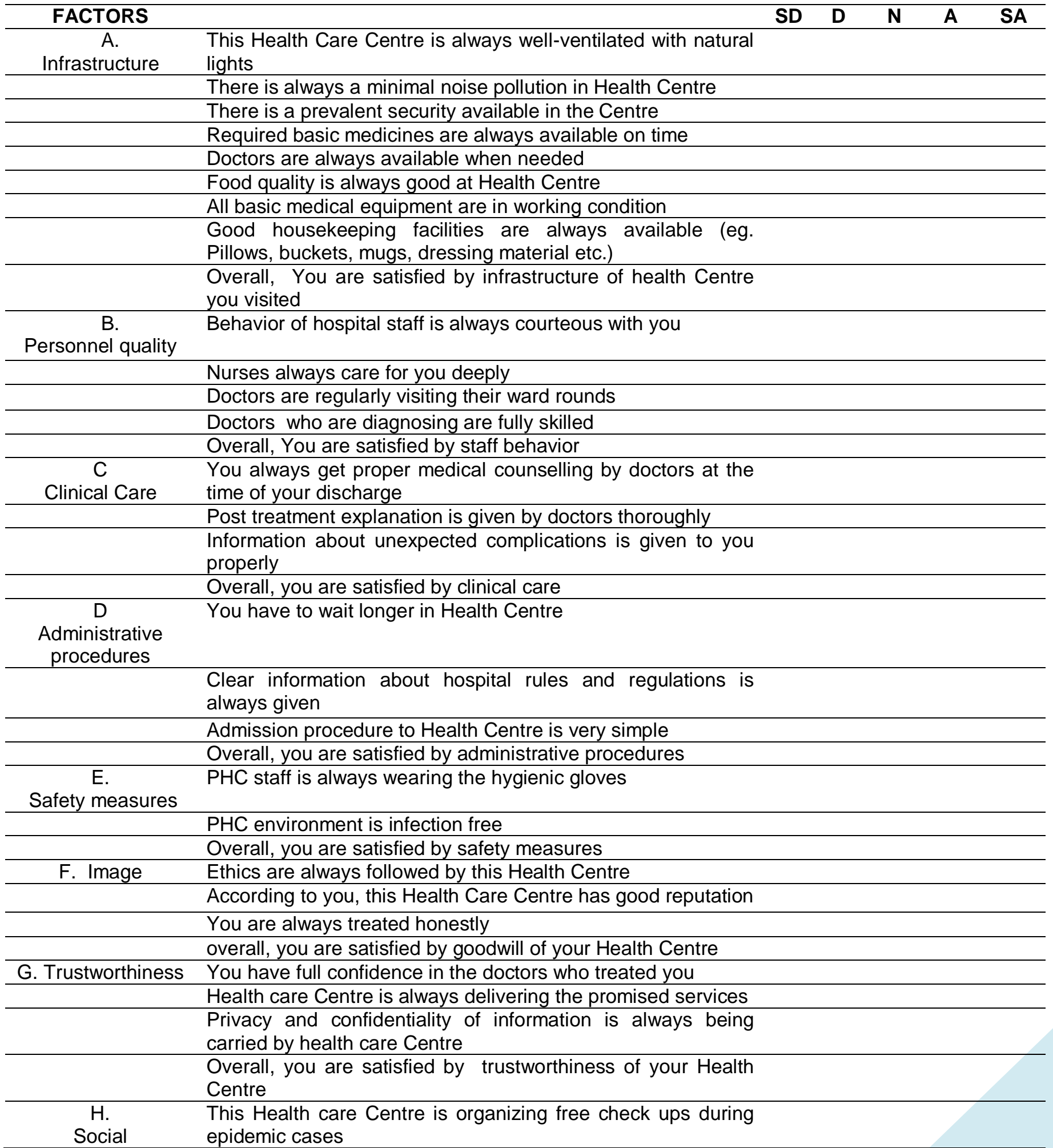


INDEPENDENT JOURNAL OF MANAGEMENT \& PRODUCTION (IJM\&P)

http://www.ijmp.jor.br

V. 10, n. 1, January - February 2019

ISSN: 2236-269X

DOI: 10.14807/ijmp.v10i1.817

Responsibility

This Service provider is arranging medical camps for needy

people

$\mathrm{SD}=$ Strongly Disagree $\mathrm{D}=$ Disagree $\mathrm{N}=$ Neutral $\mathrm{A}=$ Agree $\mathrm{SA}=$ Strongly Agree

Period of this Interview- 1 month (March 2018)

Profile of the interviewees: Demographic information on 80 respondents who participated in an interview was obtained from Zarol village. Of the 80, 40 (50\%) were male and remaining 40 (50\%) were female. Equal division between masculine and feminine was intentional so that by using independent sample T-test, we can analyze and compare the means and find out if there is any significant difference between various dimensions of service quality and gender.

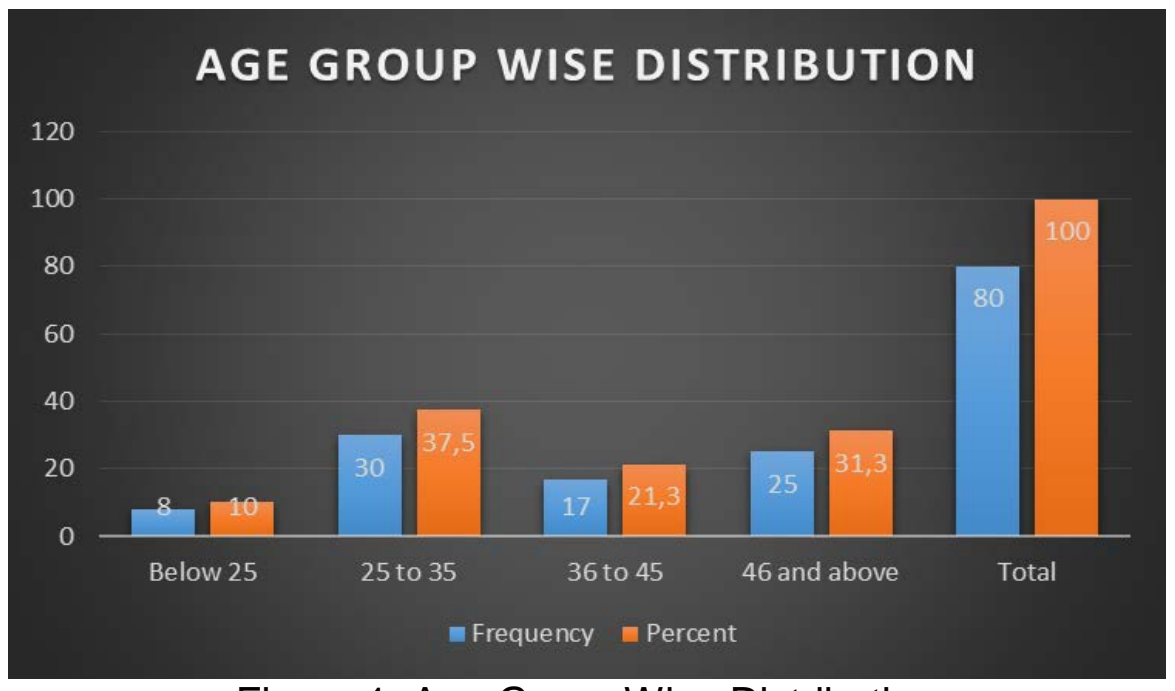

Figure 1: Age Group Wise Distribution

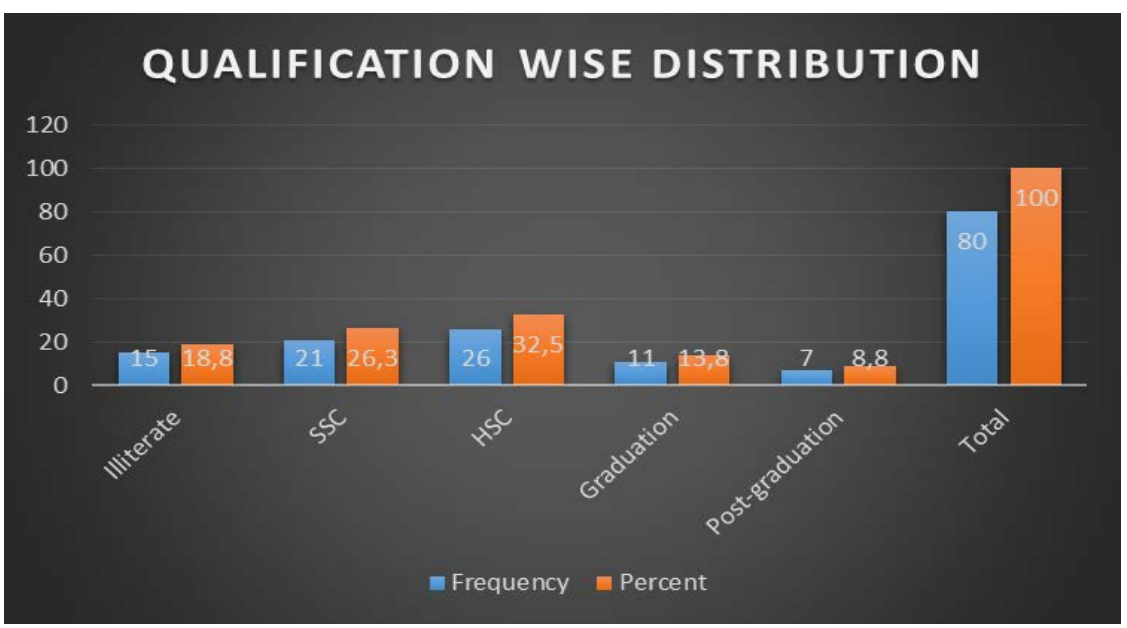

Figure 2: Qualitication wise distribution 
DOI: 10.14807/ijmp.v10i1.817

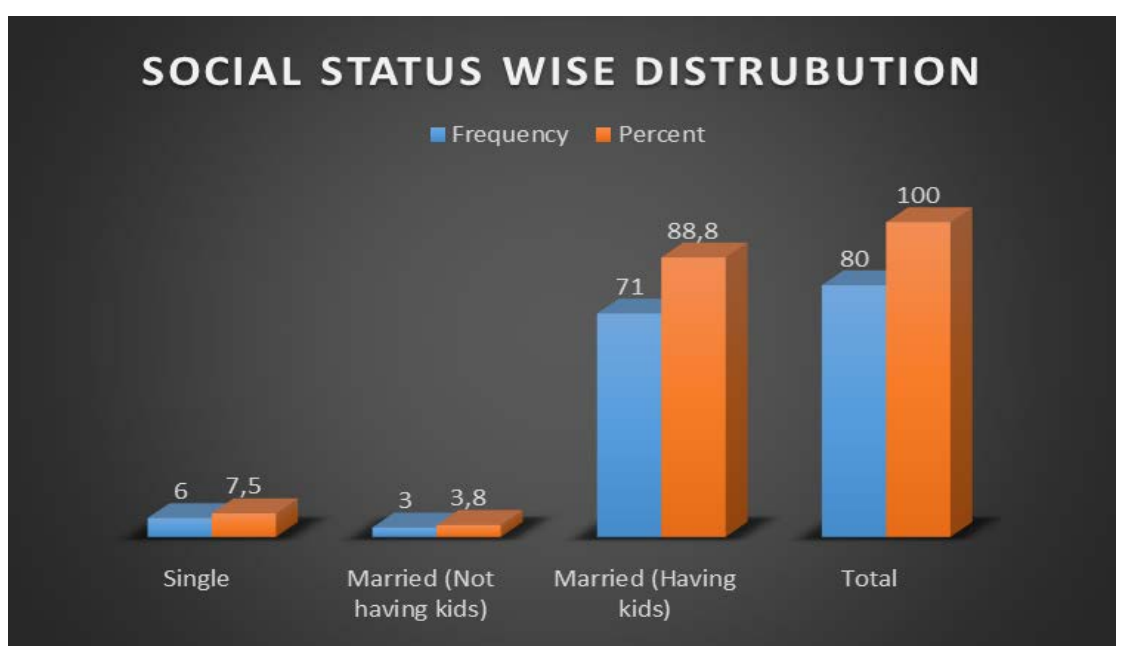

Figure 3: Social Status Wise Distribution

\subsection{Constructed Hypothesis for the study}

- H01: mean of various dimensions of service quality does not have significance difference across (or between) gender groups

- H02: mean of various dimensions of service quality does not have significance difference across (or between) age groups.

- H03: mean of various dimensions of service quality does not have significance difference across qualification

- H04: mean of various dimensions of service quality does not have significance difference across marital status

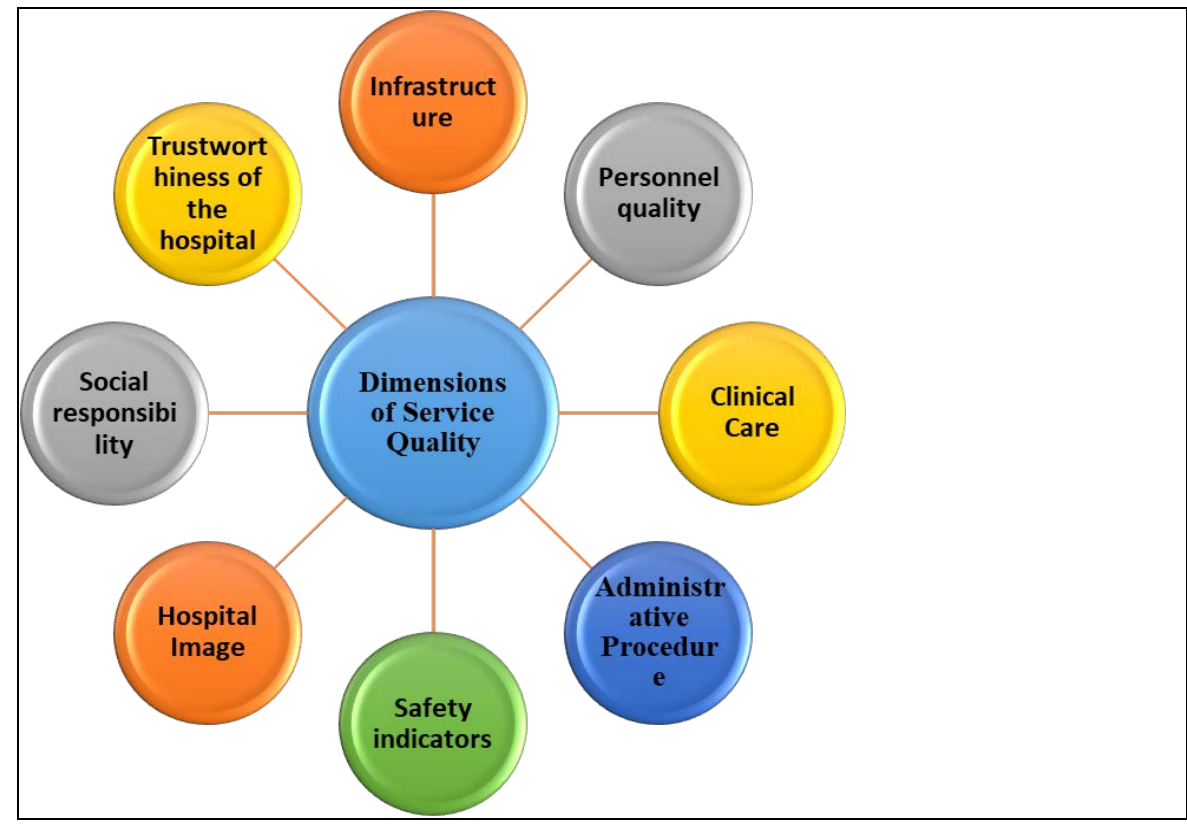

Figure 4: Main Thrust of the paper

\section{RESULTS AND DISCUSSION}


DOI: 10.14807/ijmp.v10i1.817

\subsection{Demographic Factors}

Cronbach's alpha, a (or coefficient alpha), developed by Lee Cronbach in 1951, measure reliability or internal consistency. 'Reliability' is how well a test measures what it should. Cronbach's alpha tests to see if multiple-question Likert scale surveys are reliable. These questions measure latent variables - hidden or unobservable variables those are very difficult to measure in real life. Cronbach's alpha will justify if the test which have designed is accurately measuring the variable of interest. ${ }^{3}$

We have used Cronbach's Alpha in this study to analyze that the service quality dimensions used to measure availability of health care services are reliable or not. High reliability means it measures availability of health care services and low reliability means it measures something else (possibly nothing at all)

\subsubsection{Following table shows Cronbach's Coefficient (Alpha) values for} ensuring scale validity for the given study:

Table 2: Reliability Statistics for Service quality dimensions

\begin{tabular}{cccc}
\hline $\begin{array}{c}\text { Sr. } \\
\text { No. }\end{array}$ & Dimensions & Cronbach's Alpha & $\begin{array}{c}\text { No. of } \\
\text { Items }\end{array}$ \\
\hline $\mathbf{1}$ & Infrastructure & .890 & 2 \\
$\mathbf{2}$ & Personnel quality & .981 & 5 \\
$\mathbf{3}$ & Clinical Care & .951 & 3 \\
$\mathbf{4}$ & Administrative procedures & .968 & 3 \\
$\mathbf{5}$ & Safety measures & .980 & 2 \\
$\mathbf{6}$ & Image & .958 & 3 \\
$\mathbf{7}$ & Trustworthiness & .958 & 3 \\
$\mathbf{8}$ & Social Responsibility & .519 & 8 \\
\hline
\end{tabular}

Table 3: Descriptive Statistics

\begin{tabular}{cccccc}
\hline \multicolumn{5}{c}{ Descriptive Statistics } \\
\hline & $\mathrm{N}$ & Minimum & Maximum & Mean & Std. Deviation \\
Infrastructure & 80 & 1.00 & 5.00 & 3.5813 & 1.26902 \\
Personnel quality & 80 & 1.00 & 5.00 & 2.7425 & 1.37912 \\
Clinical Care & 80 & 1.00 & 5.00 & 3.6583 & 1.33014 \\
Administrative procedures & 80 & 1.00 & 5.00 & 3.5417 & 1.36294 \\
Safety measures & 80 & 1.00 & 5.00 & 2.2937 & 1.49618 \\
Image & 80 & 1.00 & 5.00 & 3.7708 & 1.20430 \\
Trustworthiness & 80 & 1.00 & 5.00 & 3.0792 & 1.33254 \\
Social Responsibility & 80 & 1.13 & 4.38 & 3.0953 & .64914 \\
Valid N (list wise) & 80 & & & & \\
\hline
\end{tabular}

${ }^{3}$ Mohsen Tavakol and Reg Dennick. Making Sense of Cronbach's Alpha. International Journal of Medical Education. 2011; 2:53-55 Editorial 
Means scores of Infrastructure, Clinical care, administrative procedures, Image, trustworthiness, social responsibility are relatively high indicating a higher level of patient's satisfaction from PHC of Zarol. Whereas personnel quality and safety measures are having relatively low score indicating a lower level of patient's satisfaction.

\subsubsection{T- Test}

H01: mean of various dimensions of service quality does not have significance difference across (or between) gender groups

Table 4: T - Test for service quality of patient satisfaction between female and male

\begin{tabular}{ccccccc}
\hline & Gender & $\mathrm{N}$ & Mean & $\begin{array}{c}\text { Std. } \\
\text { Deviation }\end{array}$ & $\mathrm{T}$ & P-value \\
\hline Infrastructure & Female & 40 & 3.7125 & 1.15408 & .924 & .358 \\
& Male & 40 & 3.4500 & 1.37654 & & \\
Personnel quality & Female & 40 & 2.8050 & 1.38896 & -.403 & .688 \\
& Male & 40 & 2.6800 & 1.38401 & & \\
Clinical Care & Female & 40 & 3.7833 & 1.26885 & .839 & .404 \\
& Male & 40 & 3.5333 & 1.39351 & & \\
Administrative & Female & 40 & 3.5750 & 1.30959 & .217 & .828 \\
procedures & Male & 40 & 3.5083 & 1.43021 & & \\
& Female & 40 & 2.2125 & 1.45834 & .483 & .630 \\
Safety measures & Male & 40 & 2.3750 & 1.54733 & & \\
& Female & 40 & 3.6833 & 1.16929 & .647 & .519 \\
Image & Male & 40 & 3.8583 & 1.24696 & & \\
Trustworthiness & Female & 40 & 3.1167 & 1.35569 & -.250 & .803 \\
Social & Male & 40 & 3.0417 & 1.32516 & & \\
Responsibility & Female & 40 & 3.0469 & .60227 & -.665 & .508 \\
\hline
\end{tabular}

Female respondents gave highest rate to Image as it has highest mean of 3.6833 and they gave lowest rate to safety measure as it is having lowest mean of 2.2125. For male respondents Image is having highest mean of 3.8583 and safety measures are having lowest mean of 2.3750 .

All the $p$ values are $>0.05$ so they are not statistically significant at $95 \%$ confidence interval so Null hypothesis ( $\mathrm{H} 01)$ cannot be rejected so there is no significant difference between dimensions of Service Quality and Gender

\subsubsection{ANOVA Test}

H02: mean of various dimensions of service quality does not have significance difference across (or between) age groups. 
INDEPENDENT JOURNAL OF MANAGEMENT \& PRODUCTION (IJM\&P)

http://www.ijmp.jor.br

V. 10, n. 1, January - February 2019

ISSN: 2236-269X

DOI: 10.14807/ijmp.v10i1.817

Table 5: ANOVA test for service quality of patient satisfaction between age groups

\begin{tabular}{|c|c|c|c|c|c|c|c|}
\hline & $<25$ & 25 to 35 & 36 to 45 & $>=46$ & Total & $\mathrm{F}$ & $\begin{array}{c}p- \\
\text { value }\end{array}$ \\
\hline Infrastructure & $\begin{array}{c}8^{\mathrm{a}} \\
1.19 \pm 0.26^{\mathrm{b}}\end{array}$ & $\begin{array}{c}30 \\
2.92 \pm 0.86\end{array}$ & $\begin{array}{c}17 \\
4.05 \pm 0.39\end{array}$ & $\begin{array}{c}25 \\
4.82 \pm .25\end{array}$ & $\begin{array}{c}80 \\
3.58 \pm 1.27\end{array}$ & 99.15 & $\begin{array}{c}<0.0 \\
01\end{array}$ \\
\hline $\begin{array}{l}\text { Personnel } \\
\text { quality }\end{array}$ & $\begin{array}{c}8 \\
1 \pm 0.00\end{array}$ & $\begin{array}{c}30 \\
1.69 \pm 0.52\end{array}$ & $\begin{array}{c}17 \\
2.92 \pm 0.58\end{array}$ & $\begin{array}{c}25 \\
4.44 \pm 0.5 \\
5\end{array}$ & $\begin{array}{c}80 \\
2.74 \pm 1.38\end{array}$ & 161.41 & $\begin{array}{c}<0.0 \\
01\end{array}$ \\
\hline Clinical care & $\begin{array}{c}8 \\
1.17 \pm 0.18\end{array}$ & $\begin{array}{c}30 \\
2.88 \pm 0.84\end{array}$ & $\begin{array}{c}17 \\
4.25 \pm 0.22\end{array}$ & $\begin{array}{c}25 \\
4.99 \pm 0.0 \\
7\end{array}$ & $\begin{array}{c}80 \\
3.66 \pm 1.33\end{array}$ & 138.11 & $\begin{array}{c}<0.0 \\
01\end{array}$ \\
\hline $\begin{array}{l}\text { Administrative } \\
\text { procedures }\end{array}$ & $\begin{array}{c}8 \\
1.13 \pm 0.17\end{array}$ & $\begin{array}{c}30 \\
2.70 \pm 0.89\end{array}$ & $\begin{array}{c}17 \\
4.16 \pm 0.24\end{array}$ & $\begin{array}{c}25 \\
4.91 \pm 0.2 \\
5\end{array}$ & $\begin{array}{c}80 \\
3.54 \pm 1.36\end{array}$ & 118.98 & $\begin{array}{c}<0.0 \\
01\end{array}$ \\
\hline $\begin{array}{l}\text { Safety } \\
\text { measures }\end{array}$ & $\begin{array}{c}8 \\
1 \pm 0.00\end{array}$ & $\begin{array}{c}30 \\
1.17 \pm 0.36\end{array}$ & $\begin{array}{c}17 \\
2.03 \pm 0.28\end{array}$ & $\begin{array}{c}25 \\
4.24 \pm 1.0 \\
1\end{array}$ & $\begin{array}{c}80 \\
2.29 \pm 1.50\end{array}$ & 126.73 & $\begin{array}{c}<0.0 \\
1\end{array}$ \\
\hline Image & $\begin{array}{c}8 \\
1.38 \pm 0.45\end{array}$ & $\begin{array}{c}30 \\
3.18 \pm 0.79\end{array}$ & $\begin{array}{c}17 \\
4.24 \pm 0.23\end{array}$ & $\begin{array}{c}25 \\
4.93 \pm 0.1 \\
4\end{array}$ & 80 & 115.21 & $\begin{array}{c}<0.0 \\
1\end{array}$ \\
\hline $\begin{array}{c}\text { Trustworthines } \\
\text { s }\end{array}$ & $\begin{array}{c}8 \\
1 \pm 0.00\end{array}$ & $\begin{array}{c}30 \\
2.17 \pm 0.69\end{array}$ & $\begin{array}{c}17 \\
3.51 \pm 0.53\end{array}$ & $\begin{array}{c}25 \\
4.55 \pm 0.4 \\
7\end{array}$ & $\begin{array}{c}80 \\
3.08 \pm 1.33\end{array}$ & 124.47 & $\begin{array}{c}<0.0 \\
1\end{array}$ \\
\hline $\begin{array}{c}\text { Social } \\
\text { Responsibility }\end{array}$ & $\begin{array}{c}8 \\
2.58 \pm 0.81\end{array}$ & $\begin{array}{c}30 \\
2.73 \pm 0.52\end{array}$ & $\begin{array}{c}17 \\
3.11 \pm 0.39\end{array}$ & $\begin{array}{c}25 \\
3.69 \pm 0.3 \\
8\end{array}$ & $\begin{array}{c}80 \\
3.09 \pm 0.65\end{array}$ & 20.79 & $\begin{array}{c}<0.0 \\
1\end{array}$ \\
\hline
\end{tabular}

a: number of cases. b: mean \pm SD

For the age group of below 25 years, highest mean representing highest rate by respondents i.e. 2.5181 for Social Responsibility \& lowest mean of 1 for safety measures, Trustworthiness \& personnel quality. For the age group of 25 to 35 years highest mean was 3.1778 for Image and lowest mean of 1.1667 for safety measures. For the age group of 36 to 45 years, highest mean of 4.2549 for Clinical care \& lowest mean of 2.0294 for safety measures.

For the age group of above 46 years, highest mean of 4.9867 for Clinical care \& lowest mean of 3.69 for Social Responsibility.

All the $p$ values are statistically significant at $95 \%$ confidence level as all $p$ values are $<0.05$ so there is a significant difference between various dimensions of service quality and age groups. So Null hypothesis ( $\mathrm{H02}$ ) can be rejected.

\subsubsection{ANOVA test for service quality of patient satisfaction between}

\section{qualification of respondents}

H03: mean of various dimensions of service quality does not have significance difference across qualification. 
INDEPENDENT JOURNAL OF MANAGEMENT \& PRODUCTION (IJM\&P)

http://www.ijmp.jor.br

V. 10, n. 1, January - February 2019

ISSN: 2236-269X

DOI: 10.14807/ijmp.v10i1.817

Table 6: ANOVA test for service quality of patient satisfaction between qualification of respondents

\begin{tabular}{|c|c|c|c|c|c|c|c|c|}
\hline & Illiterate & SSC & HSC & Graduation & $\begin{array}{c}\text { Post- } \\
\text { Graduation }\end{array}$ & Total & $\mathrm{F}$ & $\begin{array}{c}\mathrm{p}- \\
\text { value }\end{array}$ \\
\hline Infrastructure & $\begin{array}{c}15^{a} \\
4.77 \pm 0.37\end{array}$ & $\begin{array}{c}21 \\
4.02 \pm 0.98\end{array}$ & $\begin{array}{c}26 \\
3.50 \pm 1.05\end{array}$ & $\begin{array}{c}11 \\
2.27 \pm .1 .15\end{array}$ & $\begin{array}{c}7 \\
2.07 \pm 0.93\end{array}$ & $\begin{array}{c}80 \\
3.58 \pm 1.27\end{array}$ & 16.817 & $\begin{array}{c}<0.0 \\
01\end{array}$ \\
\hline $\begin{array}{l}\text { Personnel } \\
\text { quality }\end{array}$ & $\begin{array}{c}15 \\
4.19 \pm 0.84\end{array}$ & $\begin{array}{c}21 \\
3.1524 \pm \\
1.33\end{array}$ & $\begin{array}{c}26 \\
2.44 \pm 1.16\end{array}$ & $\begin{array}{c}11 \\
1.51 \pm 0.62\end{array}$ & $\begin{array}{c}7 \\
1.49 \pm 0.71\end{array}$ & $\begin{array}{c}80 \\
2.74 \pm 1.38\end{array}$ & 14.29 & $\begin{array}{l}<0.0 \\
01\end{array}$ \\
\hline $\begin{array}{l}\text { Administrative } \\
\text { procedures }\end{array}$ & $\begin{array}{c}15 \\
4.87 \pm 0.37 \\
15 \\
4.82 \pm 0.35\end{array}$ & $\begin{array}{c}21 \\
4.17 \pm 0.98 \\
21 \\
4.02 \pm 1.08\end{array}$ & $\begin{array}{c}26 \\
3.58 \pm 1.12 \\
26 \\
3.41 \pm 1.19\end{array}$ & $\begin{array}{c}11 \\
2.12 \pm 1.18 \\
11 \\
2.15 \pm 1.21\end{array}$ & $\begin{array}{c}7 \\
2.24 \pm 0.98 \\
7 \\
2.05 \pm 0.87\end{array}$ & $\begin{array}{c}80 \\
3.66 \pm 1.33 \\
80 \\
3.54 \pm 1.36\end{array}$ & 17.65 & $\begin{array}{c}<0.0 \\
01 \\
<0.0 \\
01\end{array}$ \\
\hline $\begin{array}{c}\text { Safety } \\
\text { measures }\end{array}$ & $\begin{array}{c}15 \\
4.033 \pm 1.3 \\
3\end{array}$ & $\begin{array}{c}21 \\
2.67 \pm 1.50\end{array}$ & $\begin{array}{c}26 \\
1.79 \pm 1.02\end{array}$ & $\begin{array}{c}11 \\
1.14 \pm 0.38\end{array}$ & $\begin{array}{c}7 \\
1.14 \pm 0.38\end{array}$ & $\begin{array}{c}80 \\
2.29 \pm 1.49\end{array}$ & 15.124 & $\begin{array}{c}<0.0 \\
01\end{array}$ \\
\hline Image & $\begin{array}{c}15 \\
4.82 \pm 0.42\end{array}$ & $\begin{array}{c}21 \\
4.23 \pm 0.78\end{array}$ & $\begin{array}{c}26 \\
3.74 \pm 0.99\end{array}$ & $\begin{array}{c}11 \\
2.27 \pm 1.25\end{array}$ & $\begin{array}{c}7 \\
2.57 \pm 0.79\end{array}$ & $\begin{array}{c}80 \\
3.77 \pm 1.20\end{array}$ & 17.89 & $\begin{array}{l}<0.0 \\
01\end{array}$ \\
\hline Trustworthiness & $\begin{array}{c}15 \\
4.42 \pm 0.68\end{array}$ & $\begin{array}{c}21 \\
3.48 \pm 1.16\end{array}$ & $\begin{array}{c}26 \\
2.88 \pm 1.11\end{array}$ & $\begin{array}{c}11 \\
1.79 \pm 0.96\end{array}$ & $\begin{array}{c}7 \\
1.76 \pm 0.89\end{array}$ & $\begin{array}{c}80 \\
3.08 \pm 1.33\end{array}$ & 14.78 & $\begin{array}{c}<0.0 \\
01\end{array}$ \\
\hline $\begin{array}{c}\text { Social } \\
\text { Responsibility }\end{array}$ & $\begin{array}{c}15 \\
3.58 \pm 0.45\end{array}$ & $\begin{array}{c}21 \\
3.29 \pm 0.55\end{array}$ & $\begin{array}{c}26 \\
3.07 \pm 0.48\end{array}$ & $\begin{array}{c}11 \\
2.53 \pm 0.65\end{array}$ & $\begin{array}{c}7 \\
2.45 \pm 0.79\end{array}$ & $\begin{array}{c}80 \\
3.09 \pm 0.65\end{array}$ & 8.94 & $\begin{array}{c}<0.0 \\
01\end{array}$ \\
\hline
\end{tabular}

a: number of cases. b: mean \pm SD

For the Illiterate group, highest mean of 4.8667 for Clinical Care \& lowest mean of 3.5750 for Social Responsibility. For the SSC group, highest mean of 4.2381 for Image and lowest mean of 2.6667 for safety measures. For HSC group, highest mean of 3.7436 for Image and lowest mean of 1.7885 for safety measures. For Graduation group, highest mean of 2.5341 for Social Responsibility and lowest mean of 1.1364 for safety measures. For Post-graduation group, highest mean of 2.5714 for Image and lowest mean of 1.1429 for safety measures.

All the $p$ values are statistically significant at $95 \%$ confidence level as all $p$ values are $<0.05$ so there is a significant difference between various dimensions of service quality and qualification groups. So Null hypothesis ( $\mathrm{HO3})$ can be rejected.

\subsubsection{ANOVA test for service quality of patient satisfaction between marital status of respondents}

H04: mean of various dimensions of service quality does not have significance difference across marital status

Table 7: ANOVA test for service quality of patient satisfaction between marital status of respondents 
DOI: 10.14807/ijmp.v10i1.817

\begin{tabular}{|c|c|c|c|c|c|c|}
\hline & Single & $\begin{array}{l}\text { Married(not } \\
\text { having kids) }\end{array}$ & $\begin{array}{c}\text { Married } \\
\text { (having } \\
\text { kids) }\end{array}$ & Total & $\mathrm{F}$ & $\begin{array}{c}\mathrm{p}- \\
\text { value }\end{array}$ \\
\hline Infrastructure & $\begin{array}{c}6 \\
1.17 \pm 0.26\end{array}$ & $\begin{array}{c}3 \\
1.17 \pm 0.29\end{array}$ & $\begin{array}{c}71 \\
3.89 \pm 0.98\end{array}$ & $\begin{array}{c}80 \\
3.58 \pm 1.27\end{array}$ & 33.43 & $\begin{array}{c}<0.00 \\
1\end{array}$ \\
\hline Personnel quality & $\begin{array}{c}6 \\
1 \pm 0.00\end{array}$ & $\begin{array}{c}3 \\
1 \pm 0.00\end{array}$ & $\begin{array}{c}71 \\
2.96 \pm 1.31\end{array}$ & $\begin{array}{c}80 \\
2.74 \pm 1.38\end{array}$ & 9.92 & $\begin{array}{c}<0.00 \\
1\end{array}$ \\
\hline Clinical care & $\begin{array}{c}6 \\
1.11 \pm 0.17\end{array}$ & $\begin{array}{c}3 \\
1.44 \pm 0.19\end{array}$ & $\begin{array}{c}71 \\
3.97 \pm 1.06\end{array}$ & $\begin{array}{c}80 \\
3.66 \pm 1.33\end{array}$ & 29.30 & $\begin{array}{c}<0.00 \\
1\end{array}$ \\
\hline $\begin{array}{c}\text { Administrative } \\
\text { procedures }\end{array}$ & $\begin{array}{c}6 \\
1.06 \pm 0.14\end{array}$ & $\begin{array}{c}3 \\
1.44 \pm 0.19\end{array}$ & $\begin{array}{c}71 \\
3.84 \pm 1.13\end{array}$ & $\begin{array}{c}80 \\
3.54 \pm 1.36\end{array}$ & 24.18 & $\begin{array}{c}<0.00 \\
1\end{array}$ \\
\hline $\begin{array}{l}\text { Safety } \\
\text { measures }\end{array}$ & $\begin{array}{c}6 \\
1 \pm 0.00\end{array}$ & $\begin{array}{c}3 \\
1 \pm 0.00\end{array}$ & $\begin{array}{c}71 \\
2.46 \pm 1.51\end{array}$ & $\begin{array}{c}80 \\
2.29 \pm 1.49\end{array}$ & 4.09 & $\begin{array}{c}<0.00 \\
1\end{array}$ \\
\hline Image & $\begin{array}{c}6 \\
1.28 \pm 0.44\end{array}$ & $\begin{array}{c}3 \\
1.78 \pm 0.38\end{array}$ & $\begin{array}{c}71 \\
4.07 \pm 0.91\end{array}$ & $\begin{array}{c}80 \\
3.77 \pm 1.20\end{array}$ & 36.02 & $\begin{array}{c}<0.00 \\
1\end{array}$ \\
\hline Trustworthiness & $\begin{array}{c}6 \\
1 \pm 0.00\end{array}$ & $\begin{array}{c}3 \\
1 \pm 0.00\end{array}$ & $\begin{array}{c}71 \\
3.34 \pm 1.17\end{array}$ & $\begin{array}{c}80 \\
3.08 \pm 1.33\end{array}$ & 17.50 & $\begin{array}{c}<0.00 \\
1\end{array}$ \\
\hline $\begin{array}{c}\text { Social } \\
\text { Responsibility }\end{array}$ & $\begin{array}{c}6 \\
2.52 \pm 0.92\end{array}$ & $\begin{array}{c}3 \\
2.58 \pm 0.47\end{array}$ & $\begin{array}{c}71 \\
3.17 \pm 0.60\end{array}$ & $\begin{array}{c}80 \\
3.09 \pm 0.65\end{array}$ & 3.98 & $\begin{array}{c}<0.00 \\
1\end{array}$ \\
\hline
\end{tabular}

For the single group of respondents, highest mean of 2.5208 for Social Responsibility \& lowest mean of 1 for Personnel quality, Trustworthiness, safety measures. For Married (Not having kids group), highest mean of 2.5833 for Social Responsibility and lowest mean of 1 for personnel quality, Trustworthiness, safety measures. For married (having kids group), highest mean for Image i.e. 4.0657 and lowest mean of 2.4577 for safety measures.

All the $p$ values are statistically significant at 95\% confidence level as all $p$ values are $<0.05$ so there is a significant difference between various dimensions of service quality and marital status groups. So Null hypothesis $(\mathrm{HO4})$ can be rejected.

\section{MANAGERIAL IMPLICATIONS:}

1. Primary Health Centre must organize basic tutorial for rural people at their level of understanding

2. Staff of government hospital must be given training of how to behave with customers.

3. Doctors of Government hospitals must be given enough salary package to avoid certain issues

4. Government hospital of rural area should also progress towards Digitalized direction.

5. Enough amenities should be developed for waiting room patients.

\section{CONCLUSION:}


This study focuses on availability of Health Care Services in Zarol village as per the Indian Public Health Standards. From our research findings we can say that for H01all the $p$ values were $>0.05$ so they are not statistically significant at $95 \%$ confidence interval so Null hypothesis ( $\mathrm{HO1}$ ) cannot be rejected so there is no significant difference between dimensions of Service Quality and Gender.

For $\mathrm{H} 02$, All the $\mathrm{p}$ values are statistically significant at $95 \%$ confidence level as all $p$ values are $<0.05$ so there is a significant difference between various dimensions of service quality and age groups. So Null hypothesis ( $\mathrm{HO2}$ ) can be rejected.

For $\mathrm{H} 03$ all $\mathrm{p}$ values are $<0.05$ so there is a significant difference between various dimensions of service quality and qualification groups. So Null hypothesis (H03) can be rejected.

For H04 All the $p$ values are $<0.05$ so there is a significant difference between various dimensions of service quality and marital status groups. So Null hypothesis (H04) can be rejected.

We also faced certain limitations during our study like because of time constraint limited sample size was taken, as this survey is for remote area, Google survey form didn't work so a questionnaire was redrafted in regional language hence it took longer for field survey. Research scholar can further carry this research to map the real changes in the context of the health status of the remote area.

\section{REFERENCES:}

AMERICAN ACADEMY OF FAMILY PHYSICIANS (2015) Rural Practice, Keeping Physicians In. Retrieved October 7, 2015, from AAFP.org.

AKIN, J.; HUTCHISON, P. (1999) Health Care Facility Choice and the Phenomenon of Bypassing, Health Policy and Planning, n. 14, p. 135-151.

BABAKUS, E.; MANGOLD, W. G. (1989) Adapting the SERVQUAL scale to health care environment: an empirical assessment. In: BLOOM, P. (eds), AMA Educators Proceedings. Chicago, IL: American Marketing Association

BATES, L.; HANCOCK, L.; PETERKIN, D. (2001) A little encouragement: health services and domestic violence", International Journal of Health Care Quality Assurance, v. 14, n. 2 p. 49-56

BRADY, M. K.; CRONIN JR., J. (2001) Some new thoughts on conceptualizing perceived service quality: a hierarchical approach, Journal of Marketing, v. 65, July, p. 34-49 
CALNAN, M. (1988a) Lay Evaluation of Medicine and Medical Practice: Report of a Pilot Study, International Journal of Health Service, n. 18, p. 311-322.

CALNAN, M. W. (1998b) The Patient's Perspective, International Journal of Technology Assessment of Health Care, n. 14, p. 24-34.

CECIL G SHEPS CENTER FOR HEALTH SERVICES RESEARCH 725 Airport Road Campus Box 7590 University of North Carolina Chapel Hill, NC 27599-7590

CHAHAL, H.; SHARMA, R. D. (2004) Managing health care service quality in a primary health care centre, Metamorphosis, v. 3, n. 2, p. 112-31

CORBIN, C. L.; KELLEY, S. W.; SCHWARTZ, R. W. (2001) Concepts in service marketing for healthcare professionals, The American Journal of Surgery, v. 181, p. 1-7

CRONIN, J.; TAYLOR, S. (1992) Measuring Service Quality: A Reexamination and Extension, Journal of Marketing, v. 56, n. 3, p. 55-68.

DONGRE, Y.; MAHADEVAPPA, B.; ROHINI, R. (2010) Building access to healthcare in rural India: possibility and feasibility of low-cost medicine, International Journal of Pharmaceutical and Healthcare Marketing, v. 4, n. 4, p. 396-407

GHOSH, M. (2014) Measuring patient satisfaction, Leadership in Health Services, v. 27 , n. 3 , p. $240-254$

GILSON, I.; ALILO, M.; HEGGENHOUGEN, K. (1994) Community satisfaction with primary health care services: an evaluation undertaken in the Morogoro Region of Tanazania, Social Science and Medicine, v. 39, p. 767-80

JAYESH, P.; GARG, A. R. (2010) Measuring perceived service quality for public hospitals (PubHosQual) in the Indian context, International Journal of Pharmaceutical and Healthcare Marketing, v. 4, n. 1 p. 60-83

KANG, G.-D.; JAMES, J. (2004) Service quality dimensions: an examination of Grönroos's service quality model, Managing Service Quality: An International Journal, v. 14, n. 4, p.266-277, https://doi.org/10.1108/09604520410546806

KOTHARI, C. R.; GARG, G. (2014) Research Methodology-Methods \& Techniques, New Age Publications

MOORE, J. (2005) Is Higher Education Ready for Transformative Learning? A Question Explored in the Study of Sustainability. Journal of Transformative Education, v. 3, p. 76-91.

NEWMAN, R. D. (1998) Satisfaction with outpatient health care services in Manica Province, Mozambique, Health Policy and Planning, v. 13, n. 2, p. 174-80

PARASURAMAN, A.; ZEITHAML, V. A.; BERRY, L. L. (1988) Servqual: A multipleitem scale for measuring consumer perception of service quality, Journal of retailing, v. 64, n. 1, p. 12.

PRAKASH, G. (2015) Steering healthcare service delivery: a regulatory perspective, International Journal of Health Care Quality Assurance, v. 28, n. 2 p. 173-192

RAFTOPOULOS, V. (2005) A Grounded Theory for Patients'Satisfaction with Quality of Hospital Care. ICUs and Nursing Wen Journal, n. 22, p. 1-15.

RURAL HEALTH INFORMATION HUB (2016) Social Determinants of Health. Retrieved June 8, 2016. 
SARDANA, G. D. (2003) Performance grading of hospitals: a conceptual framework, Productivity, v. 44, n. 3, p. 450-65.

WISNIEWSKI, M.; WISNIEWSKI, H. (2005) Measuring service quality in a hospital colposcopy clinic, International Journal of Health Care Quality Assurance, v. 18 n. 3, p.217-228, https://doi.org/10.1108/09526860510594776

ZINELDIN, M. (2006) The quality of health care and patient satisfaction, International Journal of Health Care Quality Assurance, v. 19, n. 1, p. 60-92. 